\title{
The Role of Aloe vera against the toxic effect of cadmium in mice
}

\author{
H.A.A. Al-Amer SA. K. Mohammed \\ Coll. of Vet. Med./Univ. of AL-Qadysia
}

\section{Abstract}

In this study oral supplementation of aloe Vera $(1 \%)$. w/v in drink water during cd exposure $(0.1 \mathrm{mg} / \mathrm{kg}$,intraperitonelly once daily for one month) was investigated in mice for its effective value .animals exposed to cd showed a marginal decrease in glutathione (GSH) and increase white blood corpuscular (WBC) level, while most of the other clinical blood parameters like red blood cell count (RBCs), hemoglobin, $\mathrm{MCV}, \mathrm{MCH}, \mathrm{MCHC}$, recorder significant decrease at $(\mathrm{P}<\% 5)$ in cadmium exposure due to the cadmium after binding to $\mathrm{RBC}$ membrane stimulate the ROS and causes the oxidative.Damage to $\mathrm{RBC}$ membrane ratio\& platelet number, resulting in decrease in hemoglobin.Hepatic reduced GSH,while the activity of alkaline phosphate (ALP), aspartate amino transfers (AST),alanine amino transfers (ALT)\& with super oxide dismutase (SOD) activity increase significantly in cadmium exposure due to leakage of enzyme from cytosol of liver that might have entered into blood stream.Concomitant administration of aloe Vera had no protective action against the effect cadmium due to most of biochemical parameters remained un changed with aloe Vera supplementation, so that most of hepatic biochemical variables indicative of oxidative stress show protective no effect of aloe Vera on blood \&liver cadmium concentration was noted due to the toxic effect of cadmium by risk complexes formation in the body.

\section{Introduction}

Cadmium (cd) is trace element present in soil, water, cd compounds may represent a concern to environmental\& occupational health becoming as a result of natural or anthropogenic source ${ }^{(1)} \mathrm{Cd}$ has a century long his troy as human poison \&cases of acute intoxication due to oral ingestion $\left({ }^{16)}\right.$. exposure to cd cause damage \&ultimately cancer of the skin \&various organs including liver \& lungs\& testes \& ovaries \& kidneys failure ${ }^{(24)}$ abnormalities of the peripheral vascular \&disease of cerebra, vascular \&reproductive failure has also been reported in people chronically exposed to $\mathrm{cd}^{(3,18)}$. The heme metabolism is known to susceptible to alterations induced by drugs and environmental chemicals, offering the chance to use these changes as indicator of damage caused by cd.since most conventional metal chelating agents have toxic side effects or disadvantage ${ }^{(15)}$. The possibility of dietary intervention or supplementation with naturally occurring dietary nutrients'.To prevent the effects of cd in populations of risk, it of interest apositive correlation has also been established between dietary supplementation with certain of vegetables \&plants \& the reduction of toxic effects of various toxicants, environmental agents including heavy metals ${ }^{(17)}$ aloe Vera (aloe barbadensis) is used in the traditional medicine of many cultures \&said to be beneficial dermatitis \&wounds such as peptic ulcer \&burns ${ }^{(8,18)}$.the fresh gel ,juice \&formulated products \&have long been used for medical\&cosmetic purposes \&general health ${ }^{(5,25)}$ in spite of its wide use in folk remedies any influence on various heavy metals metalloid induced altered biochmical\&physiological processes have not yet been described indetalis in the present study, we report the influence of concomitant administration of aloe Vera on cd induced haemological \&hepatic disorders in male mice, blood \&liver cd concentration too were determination. 


\section{Materials and Methods}

Chemicals:-cdc12 (sigma chemical, sit louis,MO,USA).aloe Vera was purchased from a local source, (safed musalifarms, Gwalior, india) ground in a blender dissolved \&centrifuged at 5,000 $\mathrm{R}$ to remove the fibers . the supernatant stored at room temperature. small quantity of water was added to each of portion of lyophilized aloe Vera powder \&the gel was prepared.Experimental animals:-40 male mice weighting (30-35)-gm housed in same condition in stainless cages in airconditioned room with temperature maintained at 26-27 $\dot{\mathrm{c}} \& 12 \mathrm{~h}$ alternating day \&night cycles. Mice were allowed standard rat chow diet \&vegetables' metal contents of diet in p.pm(Cu10.0 ZN 40.0,MN 50.0,CO 5.0, Fe75.0) 40 mice were divided randomizly into 4 groups of 10 mice each one have10 mice were treated as below for the period of 1 month. the groups of animals included:-Group(1)as control animals, Group(2)were give Aloe -Vera at 1\% in drinking water (w/v), Group (3)-were give cadmium $0.1 \mathrm{mg} / \mathrm{kg}$ intraperitonally were given ,Group (4)-were give cadmium $(0.1 \mathrm{mg} / \mathrm{kg}+$ Aloe Vera $1 \%)$ in drinking water. once.daily the food \&water intake was recorded \&mice were weighted at the end of weeks one day after the last dose the animals were sacrificed under light ether anesthesia .blood was collected by direct cardiac puncture in heparin zed tubes . one half portion of liver \&kidneys were removed ,rinsed in cold saline, weighed \&used for various biochemical's variables \&metal analysis,the remaining was stored at $-20 \dot{c}$ wet acid digestion with $\mathrm{HNO}_{3}$ for the determination of blood GSH concentration (7). $200 \mu 1$ of whole blood was added to $200 \mu 1$ of $10 \mathrm{mM}$ solution of (2nitro benzoic acid) (DTNB) in phosphate buffer $(\mathrm{pH}=7.5)$ containing $\quad 17.5 \mathrm{mM} \quad \mathrm{Na}_{2}$ EDTA.samples were centrifuged at $2,000 \mathrm{R}$ for $6 \mathrm{~min} \&$ supernatant used for assay.super oxide dismutase (SOD) activity in brain was assayed spectrophotometrically as described $\mathrm{by}^{(5)} .2 .8 \mathrm{ml}$ of reactive mixture (xanthine $0.3 \mathrm{mM}$,EDTAo. $67 \mathrm{mM}, 150 \mu \mathrm{M}$

nitrotetraazolium blue chloride (NBT),sodium carbonate $0.4 \mathrm{M}$ \&bovine albumin $30 \mathrm{mg} / 30 \mathrm{ml}$ ) is added to $0.1 \mathrm{ml}$ sample $\& 50 \mu$ Lxanthine oxides incubated at $25 \dot{c}$ for $20 \mathrm{~min} \&$ mixed with $0.1 \mathrm{ml} 8 \mathrm{M}$ copper chloride, the color reaction was measured at $560 \mathrm{~nm}$.The activities of alkaline \&acid phosphates the (ALP) acid phosphate (ACP) were determined \&described by ${ }^{(9)}$, (a total of $0.5 \mathrm{ml}$ of the homogenate was react with $0.1 \mathrm{ml}$ of triton $\mathrm{x}-100.4 \mathrm{ml}$ quantity of alkaline or acid buffer was added to this \&the mixture was incubated at $37 \dot{\mathrm{c}}$ for $1 \mathrm{~h}$.After incubation $0.5 \mathrm{ml}$ of $30 \%$ trichloracetic acid (TCA) was added to stop the reaction the mixture was centrifuged, $2 \mathrm{ml}$ of the supernatant were mixed with $6.6 \mathrm{ml}$ of distilled water, $1 \mathrm{ml}$ of $2.5 \%$ ammonium molybdate $\& 0.4 \mathrm{ml}$ of amino-naphol sulfuric acid.optical density was measured at $620 \mathrm{~nm} \&$ the phosphorus liberated was calculated.(ALT,AST) activities were measured in liver ${ }^{(20)}$,( the assay system contain $1 \mathrm{ml}$ of buffer/substrate solution $0.2 \mathrm{ml}$ of liver homogenate $(10 \% \mathrm{w} / \mathrm{v})$ incubated for exactly $60 \mathrm{~min}$ for (ALT)\&30min for (AST) at $37 \dot{\mathrm{c}}$ in water bath $1 \mathrm{ml}$ of chromogen solution was added, mixed \&allowed to stand for $20 \mathrm{~min}$ at room temperature $10 \mathrm{ml}$ of $0.4 \mathrm{~N} \mathrm{NaoH}$ was added subsequently. the extrication was read at 505 $\mathrm{nm}$ against blank the substrate being added after deproteinization. estimation (cd concentration in blood ,liver \&kidneys were measured after wet acid digestion using microwave digestion system (CEM,MATTEWS,NC,USA,model MDs2100).cd was estimated using hydride vapor generation system (Perkin Elmer Model MHS-10) fitted with an atomic absorption spectrophotometer (A AS,perkin Elmer \&model A Analytical 100: Uberlingen, Germeny.

Statistical analysis: T-standard test was applied $^{(19)}$. 


\section{Results}

Table (1) showed the mean hemoglobin $(\mathrm{Hb})$ value in all the fore groups. There was significant decrease $(\mathrm{P}<0.05)$ in mean value of hemoglobin in cadmium chloride alone treated mice (Group 3) as compared to control (Group 1). However, the mean value in Cadmium chloride with aloe Vera whole plant supernatant(Group 4) was significantly not improved than cadmium chloride alone (Group 3).due to oxidative damage of RBCS membrane Table2:- summaries serum aspartate. Transaminase $\&$ alanine amino transaminase in control and treatment mice, there Was no significant alterations in serum AST, ALT levels.In normal mice and the values were in normal Limit. In cadmium chloride treated mice (Group 3). There was significant decrease $(\mathrm{P}<0.05)$ in AST\&ALT\&ACP Levels as compared to control (Group I).However, cadmium chloride with Aloe Vera (Group 4) compare with control(Group 1) also recorded decrease in this enzyme due to Hepatic injury following cd exposure, while depletion of SOD activity further support cd induced oxidative injury.

Table (1) some physiological parameters of blood in experimental mice.

\begin{tabular}{|c|c|c|c|c|}
\hline $\begin{array}{l}\text { Groups } \\
\text { meters }\end{array}$ & $\begin{array}{l}\mathrm{G}_{1} \\
\text { Control } \\
\mathrm{M} \pm \mathrm{SE}\end{array}$ & $\begin{array}{l}\mathrm{G}_{2} \text { aloe vera }(1 \%) \\
\mathrm{M} \pm \mathrm{SE}\end{array}$ & $\begin{array}{l}\mathrm{G}_{3} \\
\operatorname{cadmium}(0.1 \\
\mathrm{M} \pm_{\mathrm{SE}}\end{array}$ & $\begin{array}{l}\mathrm{G}_{4} \text { aloe vera } 1 \%+\text { cadmium } \\
1 \% \quad \mathrm{M} \pm \mathrm{SE}\end{array}$ \\
\hline PCV \% & $40.4 \pm 3.8$ & $40.0 \pm 3.0$ & $39.6 \pm 3.0$ & $39.8 \pm 5.0$ \\
\hline $\mathrm{RBCs}^{*} 10^{6 \mu \mathrm{I}}$ & $8.2 \pm 0.90$ & $8.45 \pm 0.6$ & $7.90 \pm 0.2$ & $8.0 \pm 0.9$ \\
\hline $\mathrm{HB}$ g/dl & $13.1 \pm 1.5$ & $13.4 \pm 1.1$ & $13.0 \pm 2.2$ & $13.2 \pm 0.3$ \\
\hline $\mathrm{MCV} \mp \mathrm{t}$ & $49.1 \pm 3.4$ & $49.0 \pm 3.3$ & $48.0 \pm 2.9$ & $47.6 \pm 3.8$ \\
\hline $\mathrm{McHc} \%$ & $32.3 \pm 1.4$ & $31.5 \pm 2.9$ & $31.2 \pm 3.2$ & $30.9 \pm 3.1$ \\
\hline $\mathrm{MCH}$ pg & $15.9 \pm 1.1$ & $15.7 \pm 1.3$ & $14.0 \pm 0.1$ & $14.5 \pm 0.9$ \\
\hline Platelet count $* 10^{3 \mu l}$ & $1.95 \pm 1.0$ & $1.88 \pm 1.32$ & $2.01 \pm 1.5$ & $2.05 \pm 1.6$ \\
\hline $\mathrm{WBCS} /{ }^{\mu 1}$ & $6.33 \pm 3.7$ & $6.30 \pm 3.5$ & $7.23 \pm 2.7$ & $7.02 \pm 2.9$ \\
\hline
\end{tabular}

- Each group contained ten mice. Mean values in columns with different superscript are significantly

variable $(\mathrm{P}<0.05)$. Mean values in columns with similar superscript are not significantly variable $(\mathrm{P}<0.05)$.

Table (2) some biochemical's parameters in experimental mice

\begin{tabular}{|c|c|c|c|c|}
\hline Parameters & $\begin{array}{c}\text { Control group } \\
(\mathrm{G} 1) \\
\mathrm{M} \pm \mathrm{SE}\end{array}$ & $\begin{array}{l}\text { Aloe Vera } 1 \% \\
(\mathrm{G} 2) \quad \mathrm{M} \pm_{\mathrm{SE}}\end{array}$ & 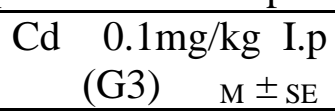 & $\begin{array}{cc}\text { Cd } & 0.1 \mathrm{mg} / \mathrm{kg}+\text { Aloe Vera } \\
& 1 \% \mathrm{G} 4 \quad \mathrm{M} \pm_{\mathrm{SE}} \\
\end{array}$ \\
\hline $\mathrm{GSH}$ & $4.3 \pm 0.01$ & $4.4 \pm 0.02$ & $4.2 \pm 0.01$ & $4.0 \pm 0.01$ \\
\hline ALP & $1.48 \pm 0.5$ & $1.5 \pm 0.13$ & $0.86 \pm 0.09$ & $0.75 \pm 0.04$ \\
\hline $\mathrm{ACP}$ & $2.47 \pm 0.21$ & $2.3 \pm 0.10$ & $2.57 \pm 0.22$ & $2.2 \pm 0.11$ \\
\hline AST & $4.0 \pm 0.01$ & $4.2 \pm 0.03$ & $3.93 \pm 0.06$ & $3.88 \pm 0.08$ \\
\hline ALT & $5.8 \pm 0.34$ & $5.4 \pm 0.24$ & $4.88 \pm 0.12$ & $4.19 \pm 0.22$ \\
\hline SOD@ & $1.63 \pm 0.14$ & $1.62 \pm 0.21$ & $1.58 \pm 0.16$ & $1.60 \pm 0.24$ \\
\hline
\end{tabular}


Table (3) the cadmium concentration in liver and kidneys in all groups

\begin{tabular}{|r|r|r|}
\hline Groups & $\begin{array}{r}\text { LIVER } \\
\mathrm{M} \pm_{\mathrm{SE}}\end{array}$ & $\begin{array}{r}\text { KIDNEYS } \\
\mathrm{M} \pm \text { SE }\end{array}$ \\
\hline G1 control & $7.2 \pm 0.32$ & $2.1 \pm 0.03$ \\
\hline G2 Aloe Vera & $7.3 \pm 0.18$ & $2.4 \pm 0.25$ \\
& & \\
\hline G3 cadmium & $8.3 \pm 0.56$ & $3.0 \pm 0.15$ \\
\hline $\begin{array}{r}\text { G4cd+Aloe } \\
\text { Vera }\end{array}$ & $8.3 \pm 0.21$ & $3.2 \pm 0.20$ \\
\hline
\end{tabular}

\section{Discussion}

The animal did not show any abnormal behavior \&none done during the experimental period .blood cadmium concentration \&changes in some physiological variables in blood of cadmium exposed animals are presented in table (1) Similar observations were recorded where cadmium after binding to RBC membrane stimulate the ROS and causes the oxidative damage to RBC membrane, resulting in decrease in hemoglobin ${ }^{(22)}$. The hemoglobin levels in mice were decreased after 2 weeks when cadmium was administered in the dose of 500 p.pm in drinking water as reported by ${ }^{(6,19)}$ in rats for compare with mice. ${ }^{(12)}$. The changes in some hepatic biochemical variable indicative of oxidative stress following exposure to cd either alone, The concentrations of biomarker enzymes namely ALT and AST were increased in serum due to leakage of enzyme from cytosol of liver that might have entered into blood stream which could have been the reason for increased levels of these enzymes in cadmium chloride treated mice, These enzymes have been proved to be an excellent indicator of cadmium chloride-induced hepatocellular damage in mice ${ }^{(21)}$. $n$ combination with aloe Vera reported in table (2) marginal decrease in reduced GSH contents was noted while oxidative glutathione contents remained un changed on cd exposure, hepatic ALP activity decreased, while no significant change in ACP activity was noted a decrease in cellular GSH concentration has been inversely correlated with lipid peroixdation in the liver ${ }^{(13,14)}$ therefore the in increase GSH could presumably protect the organ from cadmium induced lipid peroixdation A marginal decrease in hepatic GSH correlated with increase in hepatic cd concentration A significant decrease in AST\&ALT activates suggests hepatic injury following $\mathrm{cd}$ exposure, while depletion of SOD activity further support cd induced oxidative injury(table2) co-administration of aloe Vera ,particularly at the highest does, provided a significant recovery in the depleted AST\&ALT,SOD activities while the two lower doses had no effect ${ }^{(14)}$. reported a significant \&apparent role for decreased activity of SOD in the induction of aloe Vera has not been described in details ${ }^{(24)}$ Recently reported antioxidant components in aloe Vera such as isorabaichromone showed a potent anti oxidative activity \&super oxide anion scavenging activities ${ }^{(19)}$. 


\section{References}

1. Agency for Toxic substance \&disease Registry (ATSDR).1993. Toxicological profile for cd US Public Health service,Atlanta,GA.

2. Blythe d,Joyce DA.2001.Possible health hazarded associated with the use of toxic metals in semiconductor industries. J Occupy Health 42:105110.

3. Chiou HY,Hsueh YM,Liaw KF, et al.1995.Lncidence of internal up study in Taiwan. Cancer Res 55:2330.

4. Chiou HY,Huang WI,SU CL,et al.1997.Dose-response relation ship between prevalence of cerebrovasscular diseases \&glutamic pyruvic

transaminases,cadmium.33:19221924

5. Chithre P.Sajithal GB,Clandrakasan G.1998.Influence of Aloe Vera on the Glycosaminiglycans in the matrix of healing dermal wounds in mice Ethanopharmacol 60:180-188.

6. Durak.I,Canbolat O,Kavutch M,et al.1996 Activities of total cytoblasmic \&mitochondrial super oxide dismutase enzymes in sera \&plural fluids from patients with lung cancer Cline Lab Anal

7. Ellman GL.1999.Tissue sulfhydral groups Arch Biochemist 82:66-70. 10:18-20

8. Grindly G,Reynolds T.2000.The Aloe Vera phenomena review of the properties \&moden uses of the leaf parenchyma gel.J Ethno pharmacology 20:100-105.

9. Halk PB,Oser Bl,Summerson wh,1988.practical physiology chemistry .Mc Graw Hill:New York.

10. Herlihy JT,Bertrand HA,Kim JD, et al.1998.effect of Aloe vera ingestion in the rat growth,food \&fluid intake \&serum chemistry.Phytothepray Res 12:183-188.
11. Hissin PJ, Hilf R. 1973.A fluorometric method for determination of oxidized and reduced glutathione in tissues .Anal Biochem 74:214-226.

12. Hussain, G. M., D. Mishra, P. N. Singh, Ch. V. Rao and Vikaskumar (2007) : Ethnopharmacological review of native traditional medicinal plants for brain disorders.

13. Pharmacognosy Reviews.

14. Maiti S,Chatterjee AK.2000.Differetial respons of cellular antioxidant mechanism of liver \&kidey to cd exposure \&its relation to dietary protein deficiency.Environ Toxical Pharmacol 10:110-115.

15. Maiti S,Chatterjee AK. 2001.Effects on levels of glutathione \&some related enzymes in tissues after an acute cd exposure ad their relation ship to dietary deficiency.Arch Toxicol 22:10-15.

16. Mehta A,Flora SJS.2001.possible role of metal redistribution, hepatotoxicity\&oxidati ve stess in chelating agents induced hepatic\&renal metalothionein in mice.Fd Chem Toxicol 40:930-933.

17. Moore DF,O'Callaghan CA,Berlyne G,et al.2006.target sites of carcinogenic metal. In Metal Toxicology,Goyer RA,Klaassen CD.Academic Press:New York;8890.

18. Nandi P,Talukder G,Sharma A.1997.Dietary factors in cancer chemoprevention .The Nucleus 40:128-144.

19. Neiger RD,Osweiler GD.1999.Effect of subacute low lel dietary cd on rats.Fund Appl Toxicol 10:2-24.

20. Ognjanovic, B.I., S.Z. Pavlovic, S.D. Malestic, R.V. Zikic and Z.S. Saicic (2003) : Protective influence of vit.E on antioxidant defense system in the 
rats treated with cadmium Physiologic. Res. 52 : 563-57.

21. Steel,R.G.D;Torrie,J.H.(1960).Prniciple \&procedures of statistics.Mc GrawHILL BOOK Company,NewYORK.

22. Reynolds T,Dweek AC. 1999.Aloe vera leaf gel :areview update.J Ethanopharmacol 6:3-12.

23. Reitman S,Frankal S.1998.A calorimetric method for the determination of serum glutamic oxaloacetic \&glutamic pyruvic transaminases.Am J C Patthol 28:5663.

24. Robert, K.K., P.W. Michael, L. Pater, L. Ben, S.M. Robert and S.I. Glenn
(2002) : Differential hepatotoxicity induced by cadmium in Fischer 344 and Sprague-Dawley Rats. Toxicol. Sci. 65 (1) : 151-159.

25. Yagi A, Kabash YA,Okamura $\mathrm{N}$, et al.2002.antiodiant,free radical scavenging and anti-inflammatory effects of aloes in derivatives in Aloe vera.Planta Medico 68:957-960.

26. Wakchaure, S.U. (2004): Evaluation of toxico-pathological effect of some heavy metals in slaughtered swine Thesis submitted to MAFSU, Nagpur, (M.S.) India.

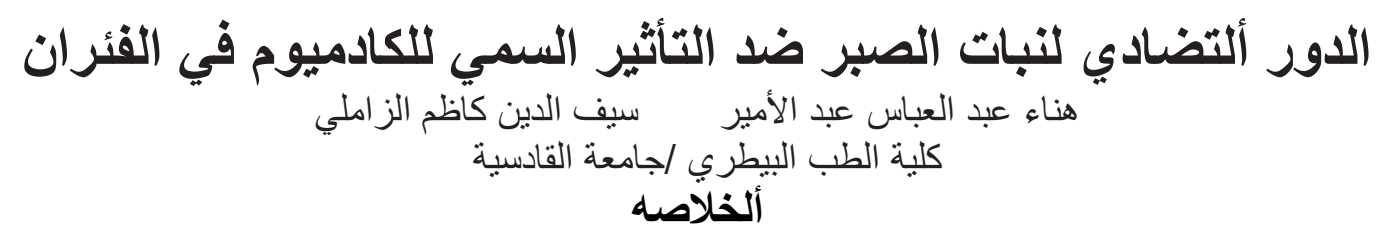

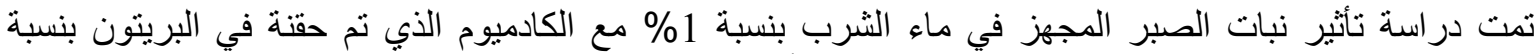

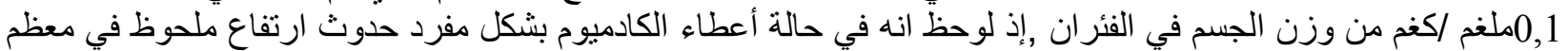

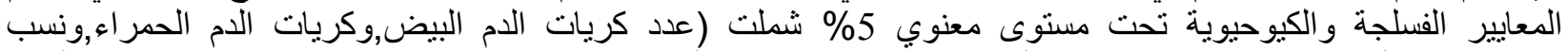

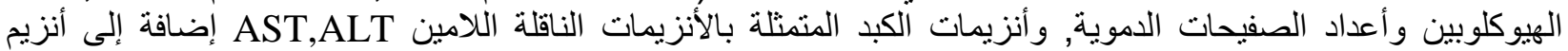

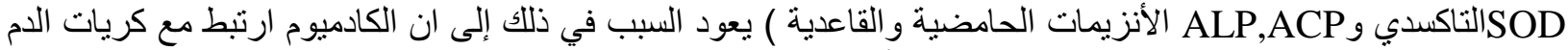

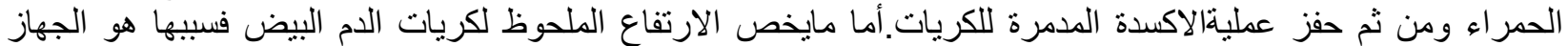

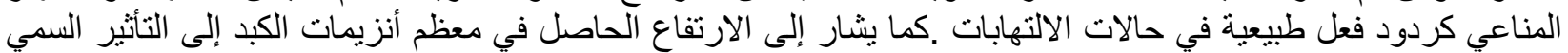

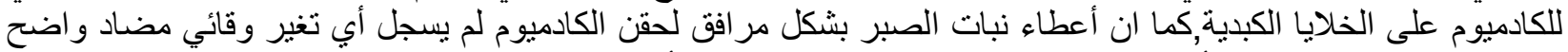

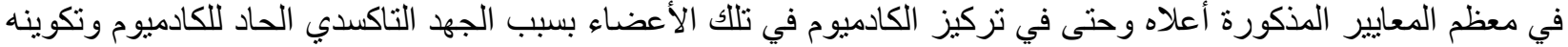

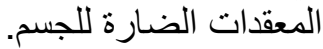

